\title{
Lactobacillus kisonensis sp. nov., Lactobacillus otakiensis sp. nov., Lactobacillus rapi sp. nov. and Lactobacillus sunkii sp. nov., heterofermentative species isolated from sunki, a traditional Japanese pickle
}

Correspondence

Koichi Watanabe

koichi-watanabe@yakult.co.jp
Koichi Watanabe, ${ }^{1}$ Junji Fujimoto, ${ }^{1}$ Yasuaki Tomii, ${ }^{1}$ Masae Sasamoto, ${ }^{1}$ Hiroshi Makino, ${ }^{1}$ Yuko Kudo ${ }^{1}$ and Sanae Okada ${ }^{2}$

\author{
${ }^{1} Y a k u l t$ Central Institute for Microbiological Research, 1796 Yaho, Kunitachi, Tokyo 186-8650, \\ Japan \\ ${ }^{2}$ NODAl Culture Collection Center, Tokyo University of Agriculture, 1-1-1 Sakuragaoka, Setagaya, \\ Tokyo 156-8502, Japan
}

Sunki is a traditional Japanese non-salted pickle product prepared from the spontaneous fermentation of the parboiled leaves and stems of red turnips, called 'otaki-kabu'. The red turnips are cultivated in Kiso county, Nagano prefecture, Japan. To prepare the pickle, the red turnips are parboiled and

Abbreviations: AFLP, amplified fragment length polymorphism; LAB, lactic acid bacteria.

The GenBank/EMBL/DDBJ accession numbers for the 16S rRNA gene sequences of strains $L$. buchneri YIT $0077^{\top}$, L. diolivorans YIT 10368 ${ }^{\top}, L$. hilgardii YIT 0269 ${ }^{\top}$, L. kefiri YIT 0222 ${ }^{\top}$, L. parabuchneri YIT 0272 ${ }^{\top}$, L. parakefiri YIT $10382^{\top}$, L. sunkii sp. nov. YIT $11161^{\top}$, L. otakiensis sp. nov. YIT $11163^{\top}$, YIT 11167, L. kisonensis sp. nov. YIT 11168 ${ }^{\top}$, L. rapi sp. nov. YIT 11204', YIT 11442, YIT 11452, YIT 11505, YIT 11510, YIT 11539, YIT 11549, YIT 11557, YIT 11635, YIT 11661 and YIT 11688 are AB429368-AB429373 and AB366385-AB366399, respectively, and for the recA gene sequences AB430354-AB430374, respectively.

A table detailing the DNA G $+C$ contents and DNA-DNA relatedness of the novel strains as compared with type strains of species in the $L$. buchneri group is available with the online version of this paper. Additional phylogenetic trees based on 16S rRNA and RecA gene sequences and constructed with the neighbour-joining, maximumparsimony and maximum-likelihood methods are also available. sometimes inoculated with dried, well-fermented sunki that was prepared the previous year as a starter. The turnips are then allowed to ferment at a low temperature during late autumn at around $10-15{ }^{\circ} \mathrm{C}$ for $1-2$ months.

During a study on the biodiversity of lactic acid bacteria (LAB) associated with the fermentation of sunki, 36 strains were isolated from 33 samples of the non-salted pickle solution used in sunki production. The samples were collected in December 2004 in Kiso county, Nagano prefecture, Japan. The novel strains were classified as belonging to the Lactobacillus buchneri species group, which consists of L. buchneri, Lactobacillus diolivorans, Lactobacillus hilgardii, Lactobacillus kefiri, Lactobacillus parabuchneri and Lactobacillus parakefiri, by a phylogenetic analysis based on $16 \mathrm{~S}$ rRNA gene sequences. Samples were taken aseptically, stored at $4{ }^{\circ} \mathrm{C}$ and pelleted by centrifugation at $20000 \mathrm{~g}$ for $10 \mathrm{~min}$. The pellet was resuspended with Nutrient Broth (BD; Difco) containing $10 \%(\mathrm{v} / \mathrm{v})$ DMSO and stored at $-80{ }^{\circ} \mathrm{C}$ until use.

Thawed samples were serially diluted with sterile saline $(0.85 \% \mathrm{NaCl})$ before being inoculated onto MRS (BD; 
Difco) agar supplemented with $0.001 \%$ sodium azide and $0.001 \%$ cycloheximide and incubated anaerobically at $30{ }^{\circ} \mathrm{C}$ for 3 days. The total cell counts for the $36 \mathrm{LAB}$ strains in the 33 samples ranged from 5.40 to $8.71 \log _{10}$ c.f.u. $\mathrm{ml}^{-1}$ (7.19 $\pm 0.94 \log _{10}$ c.f.u. $\mathrm{ml}^{-1}$; mean \pm SD). This study describes the morphological, biochemical and molecular characterization of the 36 novel strains, which could not be clearly placed within any recognized species in the L. buchneri species group.

The following strains were obtained from the culture collection of the Yakult Central Institute (YIT; Tokyo, Japan) and were used as reference strains: L. buchneri YIT $0077^{\mathrm{T}}$, L. diolivorans YIT $10368^{\mathrm{T}}$, L. hilgardii YIT $0269^{\mathrm{T}}, L$. kefiri YIT $0222^{\mathrm{T}}$, L. parabuchneri YIT $0272^{\mathrm{T}}$ and $L$. parakefiri YIT $10382^{\mathrm{T}}$. The strains used for further experiments were cultivated and maintained in MRS broth $(\mathrm{pH} 7.0)$ at $30^{\circ} \mathrm{C}$ for 1 or 2 days, unless indicated otherwise.

Chromosomal DNA was used for an amplified fragment length polymorphism (AFLP) analysis and the sequence amplification of the 16S rRNA and recA genes from the novel isolates was conducted according to the method of Watanabe et al. (2008). For discrimination of the strains, the AFLP analysis method was performed as described previously (Thompson et al., 2001), with the following modifications. Total DNA was digested with EcoRI and MseI restriction enzymes and the DNA fragments were ligated to double-stranded restriction site-specific adaptors, EcoRI-adaptors (5'-CTCGTAGACTGCGTACC-3', 5' CATCTGACGCATGGTTAA-3') and MseI-adaptors (5'TACTCAGGACTCAT- $3^{\prime}, 5^{\prime}$-GAGTCCTGAGTAGCAG-3' ${ }^{\prime}$. For the preselective and selective PCR amplification, primers EcoRI-A (5'-GACTGCATACCACCAATTCA-3') and MseICA (5'-AATGAGTCCTGAGTAGCA-3') (selective bases at the $3^{\prime}$-end are underlined) were used. The $5^{\prime}$ end of EcoRI primer was labelled with 6-carboxy-fluorescine (FAM). PCR products were analysed on an ABI PRISM 3130xl Genetic Analyzer (Applied Biosystems) in standard fragment analysis mode protocol with a GENESCAN-500LIZ size standard (Applied Biosystems). After electrophoresis, the AFLP patterns were analysed and extracted with GeneMapper software v4.0 (Applied Biosystems). A threshold fluorescence value of 250 arbitrary units was used to eliminate the background and DNA fragments of between $51-500 \mathrm{bp}$ were analysed. Bands that were positioned at the same length (DNA size) in different individual strains were assumed to be homologous and to represent the same allele. Bands of different sizes were treated as independent loci with two alleles (present or absent). Data were exported in a binary format with ' 1 ' representing the presence of a band/peak and ' 0 ' representing its absence. The data were analysed phylogenetically with InforBIO software v5.26 (Sugawara et al., 2003) by using the unweighted pair group method with arithmetic mean clustering using the Pearson correlation coefficient. The 36 strains were separated into four groups. Group A comprised strains YIT $11161^{\mathrm{T}}$, YIT 11436, YIT 11442, YIT 11539, YIT 11547, YIT 11549, YIT 11557, YIT
11574, YIT 11575, YIT 11635 and YIT 11675. Group B comprised strains YIT $11168^{\mathrm{T}}$, YIT 11510, YIT 11515, YIT 11554, YIT 11566 and YIT 11661. The strains in group C were YIT $11204^{\mathrm{T}}$ and YIT 11688 and group D comprised strains YIT $11163^{\mathrm{T}}$, YIT 11167, YIT 11194, YIT 11218, YIT 11224, YIT 11452, YIT 11461, YIT 11505, YIT 11512, YIT 11532, YIT 11535, YIT 11548, YIT 11556, YIT 11571, YIT 11663, YIT 11674 and YIT 11687 (Fig. 1).

The phylogenetic position of the 36 strains was initially investigated using the 16S rRNA gene sequence analysis as described by Miyake et al. (1998). Next, the taxonomic positions were analysed using $r e c A$ gene sequence analysis. The sequences of the forward (recA-90F) and reverse (recA-500R) primers used for the PCR amplification of the recA genes were 5'-TAYGGVCCNGAAAGTTCDGG-3' and 5'-CATVACVCCVACTTTYTCACG-3', respectively. These primers were designed from the consensus sequences of the recA genes of $L$. buchneri GenBank accession no. AJ621626, L. brevis DQ080023, L. diolivorans AJ621635, L. hilgardii AJ621647, L. kefiri AJ621650, L. parabuchneri AJ621661, L. parakefiri AJ621665, L. delbrueckii subsp. bulgaricus AJ586864 and L. fermentum AJ579534. The PCR mixture $(25 \mu \mathrm{l})$ contained $10 \mathrm{mM}$ Tris/ $\mathrm{HCl}(\mathrm{pH} 8.3)$, $50 \mathrm{mM} \mathrm{KCl}, 200 \mu \mathrm{M}$ of each dNTP, $1 \mathrm{mM} \mathrm{MgCl}_{2}, 1 \mu \mathrm{g}$ BSA, $0.5 \mathrm{U}$ Taq DNA polymerase (Takara Bio Inc.), $0.1 \mu \mathrm{M}$ each primer and $10 \mathrm{ng}$ template DNA. The amplification program consisted of one cycle of $94{ }^{\circ} \mathrm{C}$ for 2 min; 30 cycles of $94{ }^{\circ} \mathrm{C}$ for $20 \mathrm{~s}, 55^{\circ} \mathrm{C}$ for $30 \mathrm{~s}, 72{ }^{\circ} \mathrm{C}$ for $20 \mathrm{~s}$; and finally one cycle of $72{ }^{\circ} \mathrm{C}$ for $3 \mathrm{~min}$. The PCRamplified 16S rRNA and recA genes were purified using a Montage PCR Filter unit (Millipore) and were subsequently sequenced using the ABI PRISM BigDye Terminator v3.1 cycle sequencing kit (Applied Biosystems) and an ABI PRISM 3130xl Genetic Analyzer. The closest known relatives of the novel strains were determined by FASTA and sequences of closely related species were retrieved from the DDBJ/GenBank/EMBL databases. Multiple alignments of the sequences were carried out with the CLUSTAL_X program (version 1.82) (Thompson et al., 1997). Approximately $1470 \mathrm{bp}$ of the $16 \mathrm{~S}$ rRNA gene sequences (approx. $380 \mathrm{bp}$ for the recA gene) of the 36 strains and related species were used for the construction of phylogenetic trees with the neighbourjoining method (Saitou \& Nei, 1987). The statistical reliability of the tree was evaluated by bootstrap analysis of 1000 replicates (Felsenstein, 1985) and the tree topology was also confirmed with the maximum-parsimony (Fitch, 1972) and maximum-likelihood (Cavalli-Sforza \& Edwards, 1967) methods, by using PHYLIP v3.67 (Felsenstein, 2007).

The 16S rRNA gene sequence similarities between the type strains of groups A, B, C and D and the closest six neighbouring species, L. buchneri $\mathrm{YIT} 0077^{\mathrm{T}}$, L. diolivorans YIT $10368^{\mathrm{T}}, L$. hilgardii YIT $0269^{\mathrm{T}}$, L. kefiri YIT $0222^{\mathrm{T}}, L$. parabuchneri $\mathrm{YIT} 0272^{\mathrm{T}}$ and L. parakefiri YIT $10382^{\mathrm{T}}$, were $98.0-99.6 \%$. These values are considerably higher than the recommended value for species differentiation (97\%; 


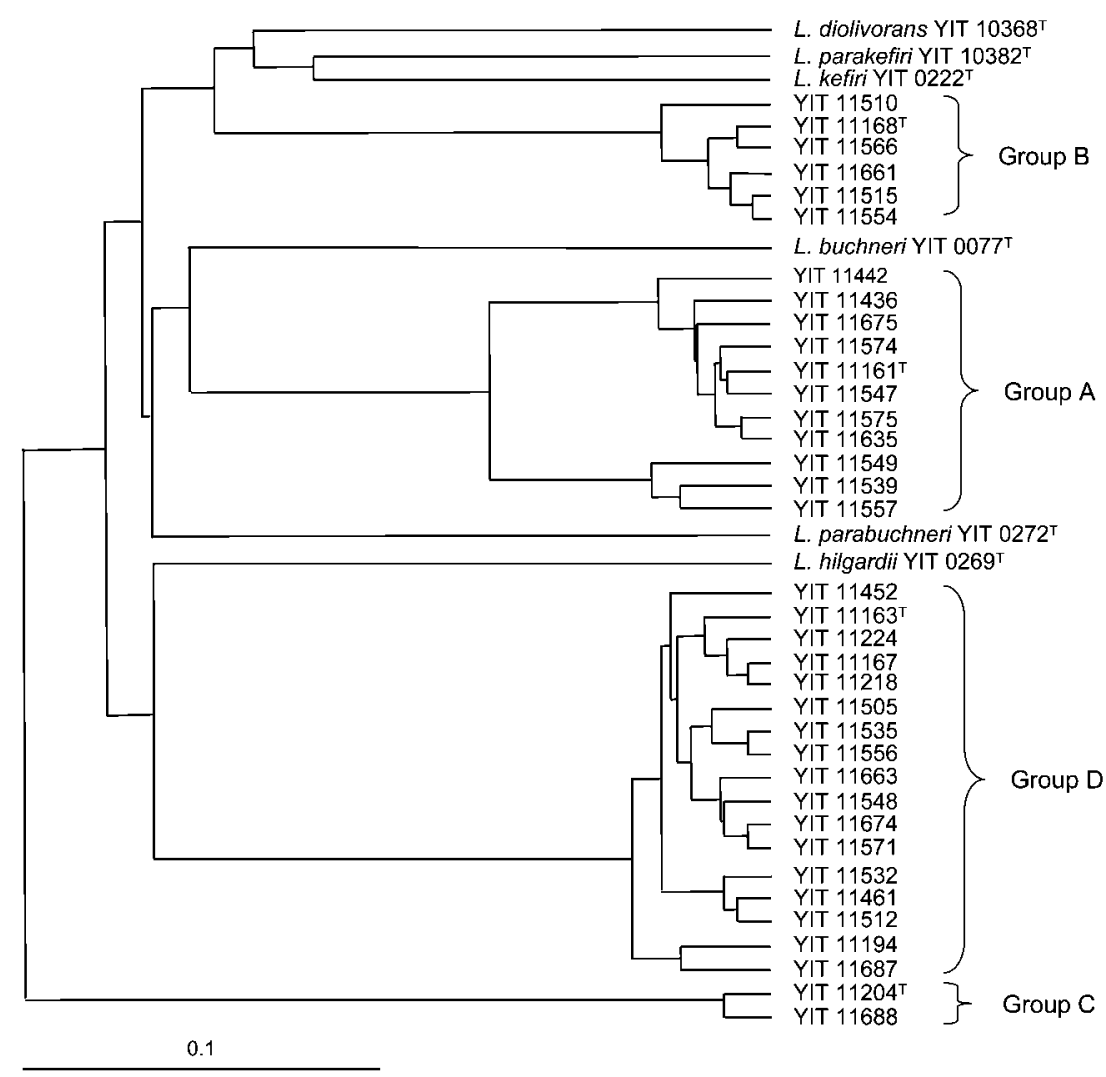

Fig. 1. Cluster analysis of digitalized AFLP fragment patterns of 36 selected $L A B$ strains isolated from sunki and closest phylogenetic relative strains. The corresponding dendrogram was constructed from the UPGMA linkage of Dice genetic distance coefficients. Bar, $10 \%$ sequence divergence.
Stackebrandt \& Goebel, 1994) (see Supplementary Fig. S1 in IJSEM Online). The similarities among the recA gene sequences of the 36 novel strains in groups A, B, C, D and the closest six neighbouring species ranged from 79.2 to $84.5 \%$. The similarity values between the strains in groups A, B, C and D were $99.7-100 \%, 100 \%, 100 \%$ and $100 \%$, respectively. Interspecies gaps within the genus Lactobacillus based on recA gene sequences normally exceed 10-15\% (Torriani et al., 2001), which suggested that these 36 novel strains should be classified into four novel Lactobacillus species. On the basis of the neighbourjoining analysis of the recA gene sequences, the novel strains did not belong to any recognized phylogenetic groups and formed four distinct subclusters, groups A, B, C and D, in the L. buchneri cluster (Fig. 2). Similar topologies were obtained by the maximum-parsimony and maximum-likelihood methods (see Supplementary Figs S2 and S3 in IJSEM Online).

For the determination of DNA-DNA relatedness and the DNA G + C content, chromosomal DNA was extracted according to the method of Marmur (1961). DNA-DNA hybridization analyses were performed between the novel strains YIT $11161^{\mathrm{T}}$, YIT $11168^{\mathrm{T}}$, YIT $11204^{\mathrm{T}}$ and YIT $11163^{\mathrm{T}}$ and L. buchneri YIT $0077^{\mathrm{T}}$, L. diolivorans YIT $10368^{\mathrm{T}}$, L. hilgardii YIT $0269^{\mathrm{T}}$, L. kefiri YIT $0222^{\mathrm{T}}, L$. parabuchneri $\mathrm{YIT} 0272^{\mathrm{T}}$ and $L$. parakefiri $\mathrm{YIT} 10382^{\mathrm{T}}$. The microdilution well technique was used as described by Ezaki et al. (1989) using a Fluoskan II microplate reader
(Labsystems) for fluorescence measurement. Reciprocal hybridization experiments were performed for every pair of strains at $41{ }^{\circ} \mathrm{C}$ for $15 \mathrm{~min}$ in the presence of $50 \%$ formamide, using biotinylated DNA and unlabelled ssDNA, which was bonded non-covalently to microplate wells. The data were calculated as the mean values of four replicate wells for each experiment. The levels of DNADNA relatedness between strain YIT $11161^{\mathrm{T}}$ and $L$. buchneri YIT $0077^{\mathrm{T}}$, L. diolivorans YIT $10368^{\mathrm{T}}$, L. hilgardii YIT $0269^{\mathrm{T}}$, L. kefiri YIT $0222^{\mathrm{T}}$, L. parabuchneri YIT $0272^{\mathrm{T}}$ and L. parakefiri YIT $10382^{\mathrm{T}}$ were $6-35 \%$; those between YIT $11168^{\mathrm{T}}$ and these reference strains were 9-36\%; those between YIT $11204^{\mathrm{T}}$ and these reference strains were 8$17 \%$ and those between YIT $11163^{\mathrm{T}}$ and the reference strains were $9-27 \%$. The values among the four novel strains, YIT $11161^{\mathrm{T}}$, YIT $11168^{\mathrm{T}}$, YIT $11204^{\mathrm{T}}$ and YIT $11163^{\mathrm{T}}$, were $8-25 \%$ (see Supplementary Table S1 in IJSEM Online). The values among the reference strains were well below the $70 \%$ cut-off value that indicates separate species (Stackebrandt \& Goebel, 1994).

To assess the DNA base composition $(\mathrm{G}+\mathrm{C}$ content), DNA was enzymically degraded into nucleosides as previously described (Mesbah et al., 1989) and then separated by HPLC. The DNA G $+\mathrm{C}$ contents of strains YIT $11168^{\mathrm{T}}$, YIT $11204^{\mathrm{T}}$, YIT $11163^{\mathrm{T}}$ and YIT $11161^{\mathrm{T}}$ were $38.8,40.3,39.6$ and $39.2 \mathrm{~mol} \%$, respectively.

Morphological, cultural and biochemical tests were performed according to standard techniques at $30{ }^{\circ} \mathrm{C}$ unless 


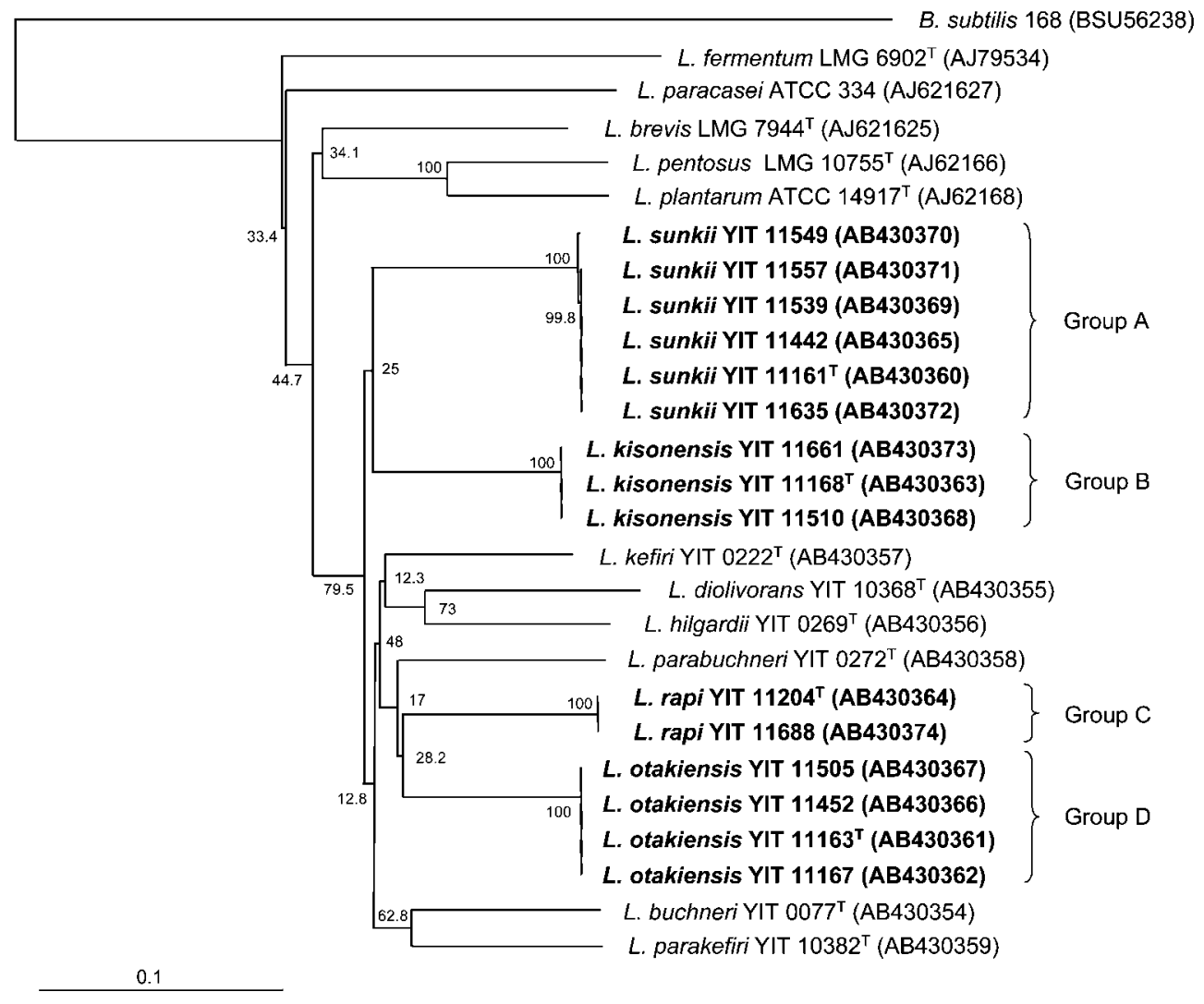

Fig. 2. Phylogenetic tree based on $\operatorname{rec} A$ gene sequences showing the relationship of the novel strains with closely related species. The tree was constructed by the neighbour-joining method on the basis of a comparison of approximately $380 \mathrm{nt}$. Bacillus subtilis was used as an outgroup. Bootstrap values (\%) based on 1000 replications are given at nodes. Bar, $10 \%$ sequence divergence.

otherwise stated. Cell shape, cell size and Gram staining were determined by using cultures grown in MRS broth at $30{ }^{\circ} \mathrm{C}$ for $16 \mathrm{~h}$. Motility was tested in MRS soft agar $(0.15 \%)$. Catalase activity was determined by using cells grown on MRS agar. Gas production from glucose was measured with a Durham tube in MRS broth. Production of dextran was assessed on MRS agar in which glucose was replaced with $2 \%(\mathrm{w} / \mathrm{v})$ sucrose. The methods of Barrow \& Feltham (1993) were used to determine growth at various temperatures and $\mathrm{pH}$ and in the presence of $\mathrm{NaCl}$ and the reduction of nitrate and production of ammonia from arginine. Carbohydrate fermentation tests were conducted by using the API 50 CHL system (bioMérieux) according to the manufacturer's instructions. The isomers of lactic acid formed from glucose were determined with a D-/Llactic acid enzymic kit (R-Biopharm AG).

Various phenotypic characteristics of the novel strains differed from those of L. buchneri (Kandler \& Weiss, 1986), L. diolivorans (Krooneman et al., 2002), L. hilgardii (Kandler \& Weiss, 1986), L. kefiri (Kandler \& Kunath, 1983), L. parabuchneri (Farrow et al., 1988) and $L$. parakefiri (Takizawa et al., 1994), the phylogenetically closest related species (Table 1). According to the data obtained, the new strains are genetically distinguishable from the recognized species of LAB and thus represent novel species. The names Lactobacillus kisonensis sp. nov., Lactobacillus otakiensis sp. nov., Lactobacillus rapi sp. nov. and Lactobacillus sunkii sp. nov. are suggested for strains YIT $11168^{\mathrm{T}}$, YIT $11163^{\mathrm{T}}$, YIT $11204^{\mathrm{T}}$ and YIT $11161^{\mathrm{T}}$, respectively.

\section{Description of Lactobacillus kisonensis sp. nov.}

Lactobacillus kisonensis (ki.so.nen'sis. N.L. masc. adj. kisonensis pertaining to Kiso, the name of the county located in the south-west area of Nagano in Japan, from where the type strain was isolated).

Cells are rod-shaped, $0.4-0.6 \times 0.8-3 \mu \mathrm{m}$ and occur singly, in pairs or in short chains comprising three or four cells. Cells are Gram-positive, catalase-negative, non-motile, non-spore-forming and facultatively anaerobic. After anaerobic growth at $30{ }^{\circ} \mathrm{C}$ for $48 \mathrm{~h}$, colonies on MRS agar are beige, with a smooth to rough surface, circular to slightly irregular and approximately $1-2 \mathrm{~mm}$ in diameter. In MRS broth, growth occurs at $10{ }^{\circ} \mathrm{C}$ but not at $45^{\circ} \mathrm{C}$. Growth occurs at $\mathrm{pH} 4.0$ and $\mathrm{pH}$ 8.5. Some strains grow at 
Table 1. Differential phenotypic characteristics among the novel species and closely related lactobacilli

Strains/species: 1, YIT $11168^{\mathrm{T}}$, YIT 11510 and YIT 11566 (L. kisonensis sp. nov.); 2, YIT $11163^{\mathrm{T}}$, YIT 11167, YIT 11452 and YIT 11505 (L. otakiensis sp. nov.); 3, YIT $11204^{\mathrm{T}}$ and YIT 11688 (L. rapi sp. nov.); 4, YIT $11161^{\mathrm{T}}$, YIT 11442 , YIT 11539, YIT 11549, YIT 11557 and YIT 11635 (L. sunkii sp. nov.); 5, L. buchneri YIT $0077^{\mathrm{T}} ; 6$, L. diolivorans YIT $10368^{\mathrm{T}} ; 7$, L. hilgardii YIT $0269^{\mathrm{T}} ; 8$, L. kefiri YIT $0222^{\mathrm{T}} ; 9$, L. parabuchneri YIT $0272^{\mathrm{T}} ; 10$, L. parakefiri YIT $10382^{\mathrm{T}}$. +, Positive; -, Negative; W, weakly positive; V, variable; ND, no data available. All strains isolated from the non-salted pickle solution used in sunki production are able to ferment $\mathrm{L}$-arabinose, ribose and maltose. None of the strains are able to ferment glycerol, erythritol, D-arabinose, Lxylose, adonitol, D-mannose, L-sorbose, rhamnose, dulcitol, inositol, mannitol, sorbitol, methyl $\alpha$-D-mannoside, $N$-acetylglucosamine, amygdalin, arbutin, salicin, cellobiose, lactose, trehalose, inulin, starch, glycogen, xylitol, $\beta$-gentiobiose, D-lyxose, D-tagatose, $\mathrm{D}$ - or L-fucose, D- or L-arabitol or 2-ketogluconate.

\begin{tabular}{|c|c|c|c|c|c|c|c|c|c|c|}
\hline Characteristic & 1 & 2 & 3 & 4 & 5 & 6 & 7 & 8 & 9 & 10 \\
\hline Growth at $10{ }^{\circ} \mathrm{C}$ & + & + & + & + & $\mathrm{ND}^{*}$ & $-\dagger$ & $\mathrm{ND}^{*}$ & $+\ddagger$ & & NDll \\
\hline \multicolumn{11}{|c|}{ Acid production from: } \\
\hline D-Fructose & - & + & + & + & + & + & + & W & + & - \\
\hline Galactose & - & + & - & $\mathrm{V}$ & - & + & + & + & + & + \\
\hline Gluconate & - & W & $\mathrm{w}$ & w & $\mathrm{W}$ & $\mathrm{W}$ & $\mathrm{W}$ & $\mathrm{W}$ & $\mathrm{W}$ & - \\
\hline D-Glucose & - & + & + & + & + & + & + & + & + & + \\
\hline 5-Ketogluconate & - & - & w & $\mathrm{V}$ & + & $\mathrm{W}$ & $\mathrm{W}$ & - & $\mathrm{W}$ & - \\
\hline Melezitose & - & - & + & $\mathrm{V}$ & + & - & - & - & + & + \\
\hline Melibiose & - & + & + & + & + & + & + & + & + & + \\
\hline $\begin{array}{l}\text { Methyl } \alpha \text {-D- } \\
\text { glucoside }\end{array}$ & - & - & + & - & - & + & - & - & - & - \\
\hline $\begin{array}{l}\text { Methyl } \beta \text { - } \\
\text { xyloside }\end{array}$ & + & - & + & V & - & + & - & - & - & - \\
\hline Raffinose & - & - & + & + & - & $\mathrm{W}$ & - & - & + & - \\
\hline Sucrose & + & - & + & + & + & - & + & - & + & - \\
\hline Turanose & V & - & + & - & - & - & - & - & - & - \\
\hline D-Xylose & + & - & + & V & + & + & + & + & - & - \\
\hline Lactate isomer & $\mathrm{L}$ & $\mathrm{DL}$ & $\mathrm{L}$ & $\mathrm{DL}$ & DL & $\mathrm{DL}$ & $\mathrm{DL}$ & DL & $\mathrm{DL}$ & $\mathrm{L}$ \\
\hline
\end{tabular}

${ }^{\star}$ Data from Kandler \& Weiss (1986).

$\dagger$ Data from Krooneman et al. (2002).

\$Data from Kandler \& Kunath (1983).

§Data from Farrow et al. (1988).

IIData from Takizawa et al. (1994).

$30{ }^{\circ} \mathrm{C}$ in the presence of $5 \% \mathrm{NaCl}$ but none grow in the presence of $8 \% \mathrm{NaCl}$. Gas is produced from glucose. Both $\mathrm{L}^{-}(85 \%)$ and D-lactate $(15 \%)$ are produced as the end products from glucose. Ammonia is produced from arginine. Nitrate is not reduced. Acid is produced from Larabinose, ribose, $\mathrm{D}$-xylose, methyl $\beta$-xyloside, maltose and sucrose. Acid is not produced from glycerol, erythritol, Darabinose, L-xylose, adonitol, galactose, D-glucose, D-fructose, D-mannose, L-sorbose, rhamnose, dulcitol, inositol, mannitol, sorbitol, methyl $\alpha$-D-mannoside, methyl $\alpha$-Dglucoside, $N$-acetylglucosamine, amygdalin, arbutin, salicin, cellobiose, lactose, melibiose, trehalose, inulin, melezitose, raffinose, starch, glycogen, xylitol, $\beta$-gentiobiose, D-lyxose, Dtagatose, D- or L-fucose, D- or L-arabitol, gluconate or 2- or 5 -ketogluconate. Acid production from turanose is strain dependent. Aesculin is hydrolysed. Dextran is not produced from sucrose. Cells do not contain meso-diaminopimelic acid in their cell-wall peptidoglycan. Phylogenetic analysis of the recA gene sequence places the species in the L. buchneri species group of lactobacilli.

The type strain, YIT $11168^{\mathrm{T}} \quad\left(=\right.$ NRIC $\quad 0741^{\mathrm{T}}=\mathrm{JCM}$ $15041^{\mathrm{T}}=$ DSM $19906^{\mathrm{T}}$ ), and the reference strains YIT 11510 and YIT 11661 were isolated from non-salted pickle solution used in producing sunki products in Kiso county, Nagano prefecture, Japan, in 2004. The DNA G+C content of the type strain is $38.8 \mathrm{~mol} \%$.

\section{Description of Lactobacillus otakiensis sp. nov.}

Lactobacillus otakiensis (o.ta.ki.en'sis. N.L. masc. adj. otakiensis pertaining to Otaki, the name for the village located in the west part of Kiso county in Nagano prefecture, Japan, from where the type strain was isolated).

Cells are rod-shaped, $0.4-0.6 \times 0.8-2 \mu \mathrm{m}$, and occur singly, in pairs or in short chains comprising three or four cells. Cells are Gram-positive, catalase-negative, non-motile, non-spore-forming and facultatively anaerobic. After anaerobic growth at $30{ }^{\circ} \mathrm{C}$ for $48 \mathrm{~h}$, colonies on MRS agar are beige, with a smooth to rough surface, circular to slightly irregular and approximately $2-3 \mathrm{~mm}$ in diameter. In MRS broth, growth occurs at $10{ }^{\circ} \mathrm{C}$ but not at $45{ }^{\circ} \mathrm{C}$. Growth occurs at $\mathrm{pH} 4.0$ and $\mathrm{pH} 8.5$. Grows at $30{ }^{\circ} \mathrm{C}$ in the presence of $5 \% \mathrm{NaCl}$ but not in the presence of $8 \%$ $\mathrm{NaCl}$. Gas is produced from glucose. Both L- $(40 \%)$ and Dlactate $(60 \%)$ are produced as the end products from glucose. Ammonia is produced from arginine. Nitrate is not reduced. Acid is produced from L-arabinose, ribose, galactose, D-glucose, D-fructose, maltose, melibiose, sucrose and gluconate. Acid is not produced from glycerol, erythritol, D-arabinose, D- or L-xylose, adonitol, methyl $\beta$ xyloside, D-mannose, L-sorbose, rhamnose, dulcitol, inositol, mannitol, sorbitol, methyl $\alpha$-D-mannoside, methyl $\alpha$-D-glucoside, $N$-acetylglucosamine, amygdalin, arbutin, salicin, cellobiose, trehalose, inulin, melezitose, starch, glycogen, xylitol, $\beta$-gentiobiose, turanose, D-lyxose, D-tagatose, D- or L-fucose, D- or L-arabitol or 2- or 5ketogluconate. Acid production from lactose and raffinose is strain-dependent. Aesculin is weakly hydrolysed. Dextran is not produced from sucrose. Cells do not contain meso-diaminopimelic acid in their cell-wall peptidoglycan. Phylogenetic analysis of the recA gene sequence places the species in the L. buchneri species group of lactobacilli.

The type strain, YIT $11163^{\mathrm{T}} \quad\left(=\mathrm{NRIC} \quad 0742^{\mathrm{T}}=\mathrm{JCM}\right.$ $15040^{\mathrm{T}}=$ DSM $19908^{\mathrm{T}}$ ), and the reference strains YIT 11167, YIT 11452 and YIT 11505 were isolated from non-salted pickle solution used in producing sunki 
products in Kiso county, Nagano prefecture, Japan, in 2004. The DNA G $+C$ content of strain YIT $11163^{\mathrm{T}}$ is $39.6 \mathrm{~mol} \%$.

\section{Description of Lactobacillus rapi sp. nov.}

Lactobacillus rapi (ra'pi. L. gen. n. rapi of a turnip, used in making sunki products).

Cells are rod-shaped, $0.4-0.6 \times 0.8-3 \mu \mathrm{m}$ and occur singly, in pairs or in short chains comprising three or four cells. Cells are Gram-positive, catalase-negative, non-motile, non-spore-forming and facultatively anaerobic. After anaerobic growth at $30{ }^{\circ} \mathrm{C}$ for $48 \mathrm{~h}$, colonies on MRS agar are beige, with a smooth to rough surface, circular to slightly irregular and approximately $2-3 \mathrm{~mm}$ in diameter. In MRS broth, growth occurs at $10{ }^{\circ} \mathrm{C}$ but not at $45{ }^{\circ} \mathrm{C}$. Growth occurs at $\mathrm{pH} 4.0$ and $\mathrm{pH}$ 8.5. Some strains grow at $30{ }^{\circ} \mathrm{C}$ in the presence of $5 \% \mathrm{NaCl}$ but none grow in the presence of $8 \% \mathrm{NaCl}$. Gas is produced from glucose. Both L- $(80 \%)$ and D-lactate $(20 \%)$ are produced as the end products from glucose. Ammonia is produced from arginine. Nitrate is not reduced. Acid is produced from L-arabinose, ribose, $\mathrm{D}$-xylose, methyl $\beta$-xyloside, D-glucose, $\mathrm{D}$-fructose, methyl $\alpha$-D-glucoside, maltose, melibiose, sucrose, melezitose, raffinose, turanose, gluconate and 5ketogluconate. Acid is not produced from glycerol, erythritol, D-arabinose, L-xylose, adonitol, galactose, Dmannose, L-sorbose, rhamnose, dulcitol, inositol, mannitol, sorbitol, methyl $\alpha$-D-mannoside, $N$-acetylglucosamine, amygdalin, arbutin, salicin, cellobiose, lactose, trehalose, inulin, starch, glycogen, xylitol, $\beta$-gentiobiose, D-lyxose, Dtagatose, D- or L-fucose, D- or L-arabitol and 2-ketogluconate. Aesculin is hydrolysed. Dextran is not produced from sucrose. Cells do not contain meso-diaminopimelic acid in their cell-wall peptidoglycan. Phylogenetic analysis of the recA gene sequence places the species in the L. buchneri species group of lactobacilli.

The type strain, YIT $11204^{\mathrm{T}} \quad\left(=\right.$ NRIC $\quad 0743^{\mathrm{T}}=\mathrm{JCM}$ $15042^{\mathrm{T}}=$ DSM $19907^{\mathrm{T}}$ ), and the reference strain YIT 11688 were isolated from non-salted pickle solution used in producing sunki products in Kiso county, Nagano prefecture, Japan, in 2004. The DNA G + C content of strain YIT $11204^{\mathrm{T}}$ is $40.3 \mathrm{~mol} \%$.

\section{Description of Lactobacillus sunkii sp. nov.}

Lactobacillus sunkii (sun'kii. N.L. gen. n. sunkii of sunki, the name of a non-salted Japanese traditional pickle).

Cells are rod-shaped, $0.4-0.8 \times 1-4 \mu \mathrm{m}$ and occur singly, in pairs or in short chains comprising three or four cells. Cells are Gram-positive, catalase-negative, non-motile, nonspore-forming and facultatively anaerobic. After anaerobic growth at $30{ }^{\circ} \mathrm{C}$ for $48 \mathrm{~h}$, colonies on MRS agar are beige, with a smooth to rough surface, circular to slightly irregular and approximately $1-3 \mathrm{~mm}$ in diameter. In MRS broth, growth occurs at $10{ }^{\circ} \mathrm{C}$ but not at $45{ }^{\circ} \mathrm{C}$.
Growth occurs at $\mathrm{pH} 4.0$ and $\mathrm{pH}$ 8.5. Some strains grow at $30{ }^{\circ} \mathrm{C}$ in the presence of $5 \% \mathrm{NaCl}$ but none grow in the presence of $8 \% \mathrm{NaCl}$. Gas is produced from glucose. Both L- $(40 \%)$ and D-lactate $(60 \%)$ are produced as the end products from glucose. Ammonia is produced from arginine. Nitrate is not reduced. Acid is produced from L-arabinose, ribose, D-glucose, D-fructose, maltose, melibiose, sucrose, raffinose, and gluconate. Acid is not produced from glycerol, erythritol, D-arabinose, L-xylose, adonitol, D-mannose, L-sorbose, rhamnose, dulcitol, inositol, mannitol, sorbitol, methyl $\alpha$-D-mannoside, methyl $\alpha$ D-glucoside, $\mathrm{N}$-acetylglucosamine, amygdalin, arbutin, salicin, cellobiose, lactose, trehalose, inulin, starch, glycogen, xylitol, $\beta$-gentiobiose, turanose, D-lyxose, D-tagatose, D- or L-fucose, D- or L-arabitol or 2-ketogluconate. Acid production from $\mathrm{D}$-xylose, methyl $\beta$-xyloside, galactose, melezitose and 5-ketogluconate is strain-dependent. Aesculin is weakly hydrolysed. Dextran is not produced from sucrose. Cells do not contain meso-diaminopimelic acid in their cell-wall peptidoglycan. Phylogenetic analysis of the recA gene sequence places the species in the $L$. buchneri species group of lactobacilli.

The type strain, YIT $11161^{\mathrm{T}} \quad\left(=\mathrm{NRIC} \quad 0744^{\mathrm{T}}=\mathrm{JCM}\right.$ $\left.15039^{\mathrm{T}}=\mathrm{DSM} 19904^{\mathrm{T}}\right)$, and the reference strains YIT 11442, YIT 11539, YIT 11549, YIT 11557 and YIT 11635 were isolated from non-salted pickle solution used in producing sunki products in Kiso county, Nagano prefecture, Japan, in 2004. The DNA G $+\mathrm{C}$ content of strain YIT $11161^{\mathrm{T}}$ is $39.2 \mathrm{~mol} \%$.

\section{References}

Barrow, G. I. \& Feltham, R. K. (editors) (1993). Cowan and Steel's Manual for the Identification of Medical Bacteria, 3rd edn. London: Cambridge University Press.

Cavalli-Sforza, L. L. \& Edwards, A. W. F. (1967). Phylogenetic analysis models and estimation procedures. Am J Hum Genet 19, 233-257.

Ezaki, T., Hashimoto, Y. \& Yabuuchi, E. (1989). Fluorometric deoxyribonucleic acid-deoxyribonucleic acid hybridization in microdilution wells as an alternative to membrane filter hybridization in which radioisotopes are used to determine genetic relatedness among bacterial strains. Int J Syst Bacteriol 39, 224-229.

Farrow, J. A. E., Phillips, B. A. \& Collins, M. D. (1988). Nucleic acid studies on some heterofermentative lactobacilli: description of Lactobacillus malefermentans sp. nov. and Lactobacillus parabuchneri sp. nov. FEMS Microbiol Lett 55, 163-168.

Felsenstein, J. (1985). Confidence limits on phylogenies: an approach using the bootstrap. Evolution 39, 783-791.

Felsenstein, J. (2007). PHYLIP (phylogeny interface package), version 3.67. Distributed by the author. Department of Genome Sciences, University of Washington, Seattle, USA.

Fitch, W. M. (1972). Toward defining the course of evolution: minimum change for a specific tree topology. Syst Zool 20, 406-416.

Kandler, O. \& Kunath, P. (1983). Lactobacillus kefir sp. nov., a component of the microflora of kefir. Syst Appl Microbiol 4, 286-294.

Kandler, O. \& Weiss, N. (1986). Genus Lactobacillus Beijerinck 1901, $212^{\mathrm{AL}}$. In Bergey's Manual of Systematic Bacteriology, vol. 2, pp. 12091234. Edited by P. H. A. Sneath, N. S. Mair, M. E. Sharpe \& L. G. Holt. Baltimore: Williams \& Wilkins. 
Krooneman, J., Faber, F., Alderkamp, A. C., Oude Elferink, S. J. H. W., Driehuis, F., Cleenwerck, I., Swings, J., Gottschal, J. C. \& Vancanneyt, M. (2002). Lactobacillus diolivorans sp. nov., a 1,2propanediol-degrading bacterium isolated from aerobically stable maize silage. Int J Syst Evol Microbiol 52, 639-646.

Marmur, J. (1961). A procedure for the isolation of deoxyribonucleic acid from microorganisms. J Mol Biol 3, 208-218.

Mesbah, M., Premachandran, U. \& Whitman, W. B. (1989). Precise measurement of the $\mathrm{G}+\mathrm{C}$ content of deoxyribonucleic acid by highperformance liquid chromatography. Int J Syst Bacteriol 39, 159-167.

Miyake, T., Watanabe, K., Watanabe, T. \& Oyaizu, H. (1998). Phylogenetic analysis of the genus Bifidobacterium and related genera based on 16S rDNA sequences. Microbiol Immunol 42, 661-667.

Saitou, N. \& Nei, M. (1987). The neighbour-joining method: a new method for reconstructing phylogenetic trees. Mol Biol Evol 4, 406-425.

Stackebrandt, E. \& Goebel, B. M. (1994). Taxonomic note: a place for DNA-DNA reassociation and $16 \mathrm{~S}$ rRNA sequence analysis in the present species definition in bacteriology. Int J Syst Bacteriol 44, 846-849.

Sugawara, H., Tanaka, N. \& Miyazaki, S. (2003). An e-workbench for the study of microbial diversity, the system design and basic functions. Microbiol Cult Coll 19, 59-67.
Takizawa, S., Kojima, S., Tamura, S., Fujinaga, S., Benno, Y. \& Nakase, T. (1994). Lactobacillus kefirgranum sp. nov. and Lactobacillus parakefir sp. nov., two new species from kefir grains. Int J Syst Bacteriol 44, 435-439.

Thompson, J. D., Gibson, T. J., Plewniak, F., Jeanmougin, F. \& Higgins, D. G. (1997). The CLUSTAL_X Windows interface: flexible strategies for multiple sequence alignment aided by quality analysis tools. Nucleic Acids Res 25, 4876-4882.

Thompson, F. L., Hoste, B., Vandemeulebroecke, K. \& Swings, J. (2001). Genomic diversity amongst Vibrio isolates from different sources determined by fluorescent amplified fragment length polymorphism. Syst Appl Microbiol 24, 520-538.

Torriani, S., Felis, G. E. \& Dellaglio, F. (2001). Differentiation of Lactobacillus plantarum, L. pentosus, and L. paraplantarum by $\operatorname{rec} A$ gene sequence analysis and multiplex PCR assay with recA gene-derived primers. Appl Environ Microbiol 67, 34503454.

Watanabe, K., Fujimoto, J., Sasamoto, M., Dugersuren, J., Tumursuh, T. \& Demberel, S. (2008). Diversity of lactic acid bacteria and yeasts in Airag and Tarag, traditional fermented milk products of Mongolia. World J Microbiol Biotechnol 24, 13131325. 